\title{
A Study of Perceived Audit Quality and Size of Big 4 Audit Office
}

\author{
Hongmei Jia \\ Texas A\&M University Commerce \\ Daniel Hsiao
Texas A\&M University Commerce
}

This study examines whether investors perceive audit quality of Big 4 accounting firms uniformly across the firms' office size. Specifically, we aim to explore whether large offices of Big 4 accounting firms associate with high level investors perceived audit quality. The empirical results from our regression analyses suggest that investors do place higher value for the audit work conducted by large size audit offices within Big-4 accounting firms. However, our further analyses indicate that the results cannot be generalized to those in non-Big-4 auditing firms.

Keywords: perceived audit quality, size of audit office, big 4 accounting firms

\section{INTRODUCTION}

This study examines whether investors perceive audit quality of Big 4 accounting firms uniformly across the firms' office size. Specifically, we aim to explore whether large offices of Big 4 accounting firms associate with high level investors perceived audit quality. The seminal piece in audit quality theory from DeAngelo (1981) suggests that auditors in large accounting firms (hereafter large firm auditors) provide higher audit quality, comparing with auditors in small accounting firms (hereafter small firm auditors), because the large firm auditors are more economically independent with their individual clients. The clientspecific quasi-rents notion serves large firm auditors with less incentive in a large client base to behave opportunistically and present a higher the perceived audit quality (DeAngelo, 1981). Since then, the association between firm-level audit quality and audit firm size has been broadly studied by various accounting research. These empirical studies indicate that higher audit quality associates with bigger audit firm, which is consistent with DeAngelo's (1981) theory. Although DeAngelo's framework does not specify a difference of the unit of auditors, it is commonly acknowledged that such a theory should apply to both the firm-level audit quality and the office-level audit quality.

From the real practice, the phenomenon we observe is that the audit quality is not homogenous across office size for the Big 4 audit firms. This can be verified by the evidence that Public Company Accounting Oversight Board (hereafter PCAOB) inspection reports continuously recognize numerous deficiencies on the individual engagements for each of the Big 4 accounting firms. Some of the above-mentioned deficiencies make financial statement users want to take another look at the Big 4 firms - as most these mistakes in Big 4 audit firms are not justifiable to auditing standard. Those deficiencies could be easily avoided if the auditing firms cautiously follow the basic audit procedure. PCAOB inspection reports do not 
disclosure the respective engagement offices, however, we have enough reasons to believe those deficiencies could not represent audit quality of Big 4 firms as a whole. The indication through PCAOB inspection reports is that audit quality is not uniform across different offices in Big 4 accounting firms.

Some of the results in recent research have indirectly indicated that the inconsistence of audit quality exists across the office. For example, some prior studies suggest that the office-level industry expertise is more precise to capture the clients' industry characteristics than that of firm-level industry expertise (Reichett and Wang, 2010; Chio et al., 2010). In addition, they also argue that when measuring the effect of economic independence, office-level of economic independence is more desirable than in firm-level. Using a sample of US firms audited by 285 unique Big 4 accounting offices during a period of 2003 to 2005, Francis and $\mathrm{Yu}(2009)$ examines directly the association between the audit quality and the audit office size of Big 4 accounting firms, and their empirical results support the prediction that larger offices of Big 4 firms are associated with higher quality audits, with controls for client risk factors and other auditor characteristics. However, Sungren and Svanstrom (2013) find a negative association between audit quality, that is the likelihood of disciple sanction, and the size of audit office for non-Big- 6 accounting firms in a sample of Swedish private firms.

As more and more studies recognize that audit quality is higher in larger office of Big 4 accounting firms. However, we find one important research question that has not been answered yet: How will investors perceive audit quality when the companies of investment interest are audited on different audit office size. Will investors perceive audit quality uniformly or perceive it differently based on the size of audit office, in particular when it is related to Big 4 audit firms? That is, we are interested to investigate whether investors will perceive audit quality of larger audit office size of Big 4 firms higher than that of smaller audit office in Big 4 firms? According to the audit quality framework in Watkins, Hillison and Morecroft (2004), audit quality needs to be considered as two different components: auditor monitoring strength and auditor reputation. Their study argues the former refers to auditor competence and auditor independence, while the latter refers to perceived competence and perceived independence; whereas these two components of audit quality usually influence each other, with a positive association in some ways. However, without further investigation this argument could not be always the case. Our study will like to answer the research question on whether investors perceive larger audit office of Big 4 accounting firm as higher audit quality.

Perceived audit quality across office size is worthy investigating because after all, investors are the capital market participants, and one of the most important users of the audit product - audited financial statements. The perceived audit quality is the determination for investors to invest or withdraw from the capital market. This question should be of interest to accounting regulators with aims to restore investors' confidence in the capital market after several failure among major accounting firms in the recent decades, such as Enron scandal on Arthur Andersen in 2001, Wirecard collapse on EY in 2019 (WSJ, 2020). Making policy to improve audit quality consistently across audit office level is one of the ways that regulators can consider. This research question will also provide long-search answer that benefits many audit firms. Auditor reputation is critical to audit quality. Given recent audit firm failure - Arthur Andersen's case, losing reputation directly leads to the collapse of this big accounting firm, audit firms have been greatly motivated to maintain audit quality at high level and keep it consistent across office. Also, from the view point of PCAOB's inspection reports, these audit firms are motivated to remove all of the deficiencies in all of their individual engagement, and achieve high level of audit quality across all the offices. Audit firms may take more actions to ensure that all the audit quality maintain high across all offices.

This study differs from prior studies in that we investigate investors' perceived audit quality on the office size of Big 4 accounting firms, whereas prior two studies only on achieved audit quality and audit office size of Big 4 audit firms, with respect to accounting accruals or earnings quality without consideration of investors as the key participants from the capital market. To the best of our knowledge, this is the first study to examine this topic exploring perceived audit quality. Thus, this study will provide incremental value on audit quality literature as well as to provide valuable insights on audit quality from investors' perspective to all the interested parties. 
The rest of the paper is organized as follows. Literature review and research development are presented in Section 2. Data and research models are described in Section 3. Section 4 presents our empirical results, and Section 5 concludes the paper.

\section{RELATED LITERATURE AND HYPOTHESIS DEVELOPMENT}

In this section, we will discuss the prior accounting literature related to (a) audit firm size and audit quality, (b) firm-level and office level audit quality, (c) audit quality and perceived audit quality, and lead to the discussion of our hypothesis development.

\section{Auditor Firm Size and Audit Quality}

DeAngelo (1981)'s framework provides the theoretical basis that large firm auditors are positively associated with audit quality. She analyzes that when an incumbent auditor discovers a breach in the client's accounting systems, the client would attempt to deter the auditor from reporting the breach by a threat of auditor termination. The auditor would have the incentive to "cheat" in order to get the present value of this client's quasi-rents. However, under this circumstance, auditors in large accounting firms would have less economic incentive to cheat because no single client is in particular important for them: if large firm auditors were caught, they would have more to lose, such as a loss of the reputation, as well as a loss of other client's base, in which may not be worth of risk. By contrast for some small-size auditing firms, one client is more important for such type of auditors, and they would have more to gain, if these auditors attempt to retain this one client by cheating. However, DeAngelo (1981) does not specify the unit of auditors in her model. Based on the above auditing theory, a few studies investigate the association between the size of auditing firms and audit quality. Francis and Krishnan (1999) use a sample of 2,608 publicly companies in the U.S. during a period of 1986-1987 to offer empirical evidence that Big 6 (now-Big 4) auditors have lower thresholds for accounting accruals to issue modified audit reports with respect to asset realization uncertainties and going concern problems. The study argues that these auditors are more conservative, which means "that Big 6 auditors are more likely to signal asset realization and going concern problems for high-accrual firms through modified audit reports" (Francis and Krishnan, 1999). Another study in Becker, Defond, Jiambalvo, and Subramanyam (1998) by testing a sample of 10,379 Big 6 (now Big 4) and 2,179 non-Big 6 firm-years, the authors find that audits conducted by Big 6 (now-Big 4) audited financial statements present lower abnormal accruals, suggesting those financial statements that had been audited by Big 6 (or now- Big 4) accounting firms have higher earning quality. Using a different survey methodology, Nelson, Elliott and Tarpley (2002) report evidence about 515 particular experiences by 253 auditors in one Big 5 firm who have had with clients identified the attempt of earnings management. The study presents the evidence that managers are more prone to engage in earning management, and the corresponding auditors require their clients to adjust their earning management based on the structure (or unstructured) of transactions in an increase (decrease) current-year income.

\section{Firm-Level and Office-Level of Audit Quality}

The above-mentioned audit theory in DeAngelo (1981) could apply to the office-level on audit quality. Within an accounting firm, a big office will possess better economic independence comparing to that of a small office, and generate lesser economic incentive to scarify audit quality for keeping their clients. We argue that audit at office-level will provide a more accurate perspective of audit quality with regard to audit competence. Audit staffs in Big 4 accounting firms, within the unit of office, have more intensive knowledge and experience sharing capacity which is benefited by their nature of decentralized organizations. Among empirical studies with research evidence focusing on the office-level audit quality, Wallman (1996) advocates that audit independence and audit quality should take into consideration in office-level, whereas Reynolds and Francis (2000) find that a greater audit quality to protect auditors' reputation for larger clients measured relatively by the size of office-level in Big 5 firms. The statement is also supported in accounting practice that audit office is the unit which does the audit work and makes the audit report decision. Ferguson, Francis and Stokes (2003) examine Big 5 auditing firms to the Australian 
audit market pricing differs for those with firm-level industry expertise and those of office-level expertise. Their result shows that the audit market only gives the premium to the audit expertise when the auditor is industry expertise at both the city level and the nation level. For those in audit expertise only at firm-level, their results do not indicate any premium earned. Interestingly, in a study of US Big 5 firms audit market, Francis, Reichelt and Wang (2005) find a similar result by examining the pricing of Big 5 industry leadership, and they find that office-level and firm-level industry expertise jointly affect audit fees.

Jia and Gates (2018) examine the relationship between size of audit office and clients' bank loans costs, and they report loans spread is negatively associated with audit office size. Their further analyses confirm that client characteristics are attributable to the association. Testing a sample of US firms audited by 285 unique Big 4 offices during 2003 to 2005, Francis and $\mathrm{Yu}$ (2009) indicate that audit quality associates with office size of Big 4 firms, which is evidenced by larger offices of Big 4 auditors are associated with higher audit quality with controls for client risk factors and other auditor characteristics. In their empirical study, the key variable of interest in audit quality is proxy by (a) the client accrual quality, (b) the benchmark earnings targets, and (c) the auditor's propensity to issue a going-concern report; whereas their expectations are that audit clients in larger offices are related to smaller abnormal accruals, less likely to meet benchmark targets, and more likely to issue a going-concern report. Both OLS models (for accounting accrual tests) and probit models (for earnings benchmark tests, and going-concern tests) are applied, Francis and $\mathrm{Yu}$ (2009) use the former models and report that larger audit office is associated with smaller abnormal accruals, while the latter models demonstrate that clients audited by larger offices are less likely to report small earnings and small earnings increases. Further analyses also offer evidence that auditors in larger offices are more likely to issue going-concern reports than those in smaller offices. Therefore, their study concludes that larger offices of Big 4 auditors are associated with higher audit quality. However, Sungren and Svanstrom (2013) examine how audit quality varies with the audit firms and audit office size in a unique setting of Swedish private firms. They find no significant difference on audit quality based on the likelihood of sanctions between Big-4 firms and Big-6 firms, but it is much higher to receive sanctions for auditors in non-Big 6 auditing firms.

\section{Audit Quality and Perceived Audit Quality}

Due to the difficulty to directly observe audit quality in practice, accounting researchers apply various measurements to proxy for audit quality, of which commonly used by audit size, and audit fees, in addition to research method by performing survey measure-- a most direct way to perceived audit quality. For example, by a participation of 241 Floridian local government finance directors, Lowensohn et al. (2007) survey the perception of government finance directors on their perceived audit quality subsequent to Big 5 auditors were hired to perform the audits. It is not supported that directors uniformly perceive Big 5 auditors as high audit quality based on the survey findings, and conclude that auditors in Big 5 firms are not consistently associated with the increased perceived audit quality. With a limitation of research generalization for a sample survey on a limited number of investors, there is a growing number of empirical studies examining market reaction to infer the perceived audit quality from investors. Teoh and Wong (1993) are among the earlier studies that compare the earnings response coefficient (hereafter ERC) between then-Big 8 and non-Big 8 accounting firms. Their findings state that ERCs of Big 8 clients are statistically significantly higher than those ERCS of non-Big 8 clients, offering the evidence that investors' response to an earnings surprise is stronger for companies audited by Big- 8 firms than for companies audited by non-Big 8 firms. The implication in their study suggests that investors perceive higher audit quality with audits from Big-8 audit firms, in contrast to findings in Lowensohn et al. (2007). There are other studies conducting a similar method by employing ERC as the proxy of perceived audit quality, i.e., Ghosh and Moon (2005) and Francis and Ke (2006). Ghosh and Moon (2005) test the association between perceive audit quality (by ERC) and auditor tenure, with an expectation that investors perceive longer auditor tenure as higher earning quality, and their findings are empirically supported. By focusing on firms' mandatory disclosure of fees to audit services and non-audit services paid to their current auditors, Francis and $\mathrm{Ke}$ (2006) study on whether investors perceive earnings quality is impacted by a then imposed 
disclosure requirement in Security Exchange Commission (SEC). Their study indicates that investors have presented lower earning quality perception for firms paid to the auditors' higher non-audit fees.

\section{Hypothesis Development}

Following the above discussion, we learn that audit quality is positively associated with the size of audit office. Following Francis, Reichelt and Wang (2005) and Francis and Wu (2009), our study also considers audit size at office-level instead of at firm-level only due to the prior studies on the size of audit office matters to audit procedure conducted and audit task undertaken by office-level, in addition to the Big-4 auditing firms with decentralized organization that contributes to audit quality not uniform across offices. According to the two components- auditor reputation and auditor monitoring strength, auditor monitoring strength refers to auditor competence and auditor independence. Auditor reputation refers to perceived competence and perceived independence (Watkins et al. 2004). Following this framework, Francis and $\mathrm{Yu}$ (2009) present evidence that auditors in larger office of Big-4 firms are more competitive than those in small office. From the view of auditor reputation, Teoh and Wong (1993) document that investors perceive Big-8 audit firms as high audit quality, which presents evidence that at firm-level, auditors in Big-8 (now Big-4) auditing firms are perceived more competitive than auditors in non-Big-8 auditing firms. Therefore, we propose the hypothesis that auditors in large office of Big-4 accounting firms are perceived more competitive than those in small office of Big-4 firms. Our research hypothesis is presented in the following:

H1: Investors perceive auditors in large office of Big-4 accounting firms provide higher quality than those in small office of Big-4 firms.

\section{RESEARCH METHOD}

In this section, we will discuss research model and variables applying to the tests, and a discussion of data and sample. Then descriptive statistics and correlation matrix are presented and discussed.

\section{Empirical Model and Variables}

Following Ohlson (1995)'s valuation model, we use the following regression model to investigate whether investors perceive high audit quality is associated with large office of Big-4 audit firms:

$$
\begin{aligned}
& \text { Price }=\theta_{0}+\theta_{1} B V E+\theta_{2} N I+\theta_{3} \text { SaleGRW } 2+\theta_{4} \ln O F F I C E+\theta_{5} \ln O F F I C E \times B V E+\theta_{6} \operatorname{lnOFFICE} \times N I \\
& +\theta_{7} \text { lnOFFICE } \times \text { SaleGRW2 }+ \text { Industry Dummies }+ \text { Year Dummies }+\mu
\end{aligned}
$$

Following Francis and Yu (2009), office fees equal an office's total audit fees each year. Office fees (OFFICE) are used as proxy for office size. Taking log function for office fees (InOFFICE) as a result of skewness in the distribution of office fees. For the dependent variable, Price equals to common stock price per share at the end of three months after fiscal year-end. For the other control variables, $\boldsymbol{B} \boldsymbol{V} \boldsymbol{E}=$ book value

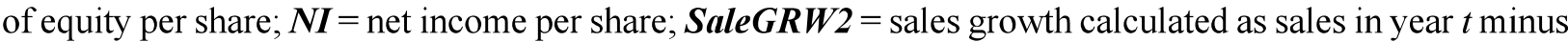
sales in year $t-2$ scaled by sales in year $t-2$. The variables of interest are $\theta 5$ and $\theta 6$, which are the valuation coefficients on book value of equity and earnings.

\section{Sample and Descriptive Statistics}

\section{Data and Sample}

Sample is constructed from Audit Analytics and Compustat. Auditor-specific variables are from Audit Analytics database and financial statement data are obtained from Compustat. Our sample includes all of the firms that have been audited by Big 4 offices during the fiscal years of 2008-2012. Following Francis and Yu (2009), the specific office is identified from the firm's location which is obtained from Audit Analytics. Following research method in related previous studies, we remove the entire financial industries sector (SIC codes 60-69) and regulated industries sector (SIC codes 44-49) from the sample. The final sample includes 7,194 firm-year observations over 2008 - 2012 period. 


\section{Descriptive Statistics}

Table 1 presents descriptive statistics for all the variables. In order to eliminate outliers, all the continuous variables are winsorized at the top and bottom one percent. As shown in Table 1, the mean and median of the common stock price per share at the end of three months after fiscal year-end (prccq_1) are 22.35 and 16.99. The mean and median of the book value of equity per share (bve) are 707.05 and 307.56. The mean and median of the net income per share variable (ni_share) are 64.84 and 20.64. The mean and median of the office fees (Inoffice) variable are 21.87 and 21.90. All the variables statistics are consistent with the sample statistics of previous studies.

TABLE 1

SUMMARY STATISTICS $(2008$ - 2012)

\begin{tabular}{lrrrrrr}
\hline VarName & Obs & Mean & SD & Min & Median & Max \\
\hline prccq_l & 7194 & 22.35 & 18.482 & .17 & 16.99 & 56.5 \\
bve & 7194 & 707.05 & 837.347 & -5.381 & 307.5645 & 2499.323 \\
ni_share & 7194 & 64.84 & 107.034 & -41.027 & 20.6355 & 269.12 \\
sgrow2 & 7194 & 0.12 & 0.349 & -.4196343 & .0688398 & 1.590197 \\
lnoffice & 7194 & 21.87 & 0.164 & 21.56492 & 21.89687 & 22.11508 \\
bve_office & 7194 & 15468.65 & 18328.217 & -119.0012 & 6730.603 & 55272.73 \\
ni_share_office & 7194 & 1418.66 & 2342.566 & -907.3154 & 451.8039 & 5951.61 \\
sgrow2_office & 7194 & 2.61 & 7.634 & -9.280245 & 1.500513 & 35.16734 \\
\hline
\end{tabular}

\section{Correlation Matrix}

Table 2 reports Pearson (on the upper right) and Spearman's (on the lower left) Correlation Coefficients among all the variables. As shown in Table 2, prccq_1 is positively correlated with bve, sgrow 2 , sgrow2_office at $\mathrm{p}<0.005$ significant level. At the $(\mathrm{p}<0.001)$ significant level, the variable prccq_1 is positively correlated with ni_share, Inoffice, bev_office, and ni_share_office. The correlations noted above are consistent with our prediction and with prior accounting literature. 


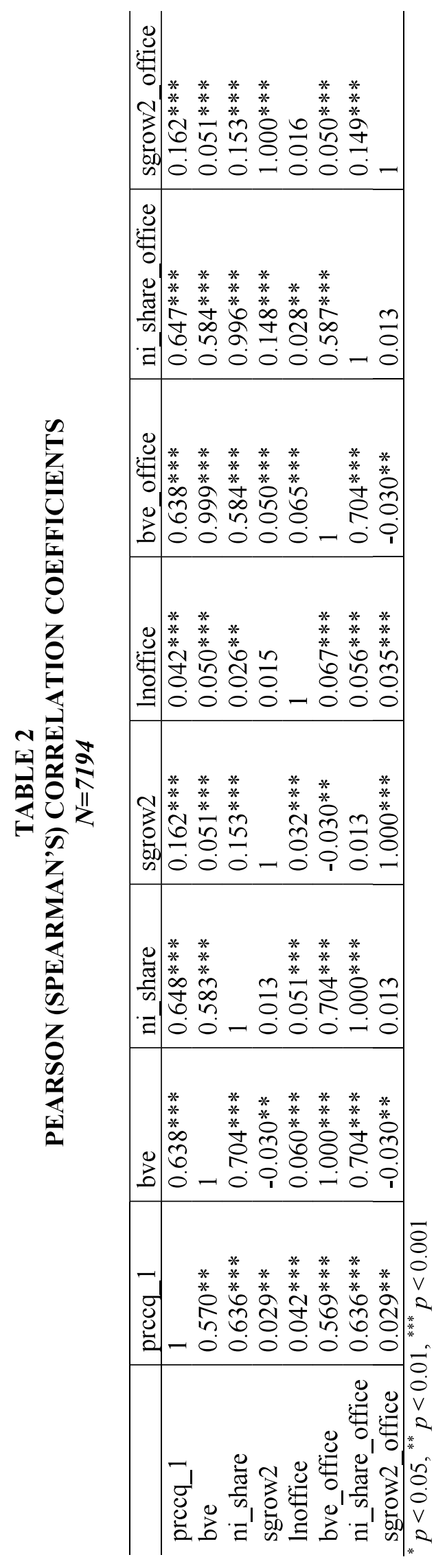

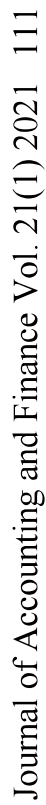




\section{EMPIRICAL RESULTS}

In this section, we will first present regression results for our constructed sample of Big 4 auditing firms. Then our further analyses will expand and report the empirical results for full sample that contains sample in Big 4 and non-Big 4 firms.

\section{Regression Results for Constructed Sample}

We estimate Equation (1) using our constructed sample $(\mathrm{N}=7,194)$ and Table 3 presents the regression results. The coefficient on bve office is significantly positive $(0.0056$, t-statistic $=3.13)$. The coefficient on bve is statistically significant $(0.128$, t-statistic $=3.27)$. The coefficient on Inoffice is marginally significant and positive $(2.54$, t-statistic $=2.54)$. However, the coefficient on ni_share_office is insignificant. Overall, the findings support the hypothesis that investors place higher book value of equity on those large size audit offices among Big-4 auditing firms.

TABLE 3

BIG - 4 SAMPLE REGRESSION RESULTS

\begin{tabular}{|c|c|c|c|}
\hline & $\begin{array}{l}\text { (1) } \\
\text { prccq_1 }\end{array}$ & $\begin{array}{l}\text { (2) } \\
\text { prccq_1 }\end{array}$ & $\begin{array}{l}\text { (3) } \\
\text { prccq_1 }\end{array}$ \\
\hline bve & $\begin{array}{l}0.0123^{* * *} \\
(55.63)\end{array}$ & & $\begin{array}{l}0.128^{* *} \\
(3.27)\end{array}$ \\
\hline ni_share & & $\begin{array}{l}0.105^{* * *} \\
(63.59)\end{array}$ & $\begin{array}{l}-0.226 \\
(-0.75)\end{array}$ \\
\hline sgrow2 & & & $\begin{array}{l}78.82 \\
(1.21)\end{array}$ \\
\hline lnoffice & & & $\begin{array}{l}3.187^{*} \\
(2.54)\end{array}$ \\
\hline bve_office & & & $\begin{array}{l}0.00559^{* *} \\
(3.13)\end{array}$ \\
\hline ni_share_office & & & $\begin{array}{l}0.0138 \\
(1.00)\end{array}$ \\
\hline sgrow2_office & & & $\begin{array}{l}-3.513 \\
(-1.18)\end{array}$ \\
\hline _cons & $\begin{array}{l}-3.035^{*} \\
(-2.22) \\
\end{array}$ & $\begin{array}{l}3.277^{*} \\
(2.05)\end{array}$ & $\begin{array}{l}-71.33^{* *} \\
(-2.60)\end{array}$ \\
\hline$N$ & 7194 & 7194 & 7194 \\
\hline
\end{tabular}

\section{Regression Results for Full Sample}

We estimate Equation (1) using full sample $(\mathrm{N}=11,174)$, which contain data from Big-4 firms and nonBig-4 firms, and Table 4 presents the empirical results. The coefficient on bve_office is marginally significant and negative $(-0.00096, \mathrm{t}$-statistic $=-2.26)$. The coefficient on bve is still statistically significant and positive $(0.03$, $\mathrm{t}$-statistic $=2.88)$. The coefficient on lnoffice is significantly positive $(1.26, \mathrm{t}$-statistic $=$ 37.79). The coefficient on ni_share_office is also significantly negative $(-0.0054$, t-statistic $=-2.8)$. In summary, the above results suggest we cannot generalize the finding to all the auditing firms. 
TABLE 4

FULL SAMPLE REGRESSION RESULTS

\begin{tabular}{|c|c|c|c|}
\hline & $\begin{array}{l}\text { (1) } \\
\text { prccq_1 }\end{array}$ & $\begin{array}{l}\text { (2) } \\
\text { precq_1 }\end{array}$ & $\begin{array}{l}\text { (3) } \\
\text { precq_1 }\end{array}$ \\
\hline bve & $\begin{array}{l}0.0148^{* * *} \\
(73.31)\end{array}$ & & $\begin{array}{l}0.0266^{* *} \\
(2.88)\end{array}$ \\
\hline ni_share & & $\begin{array}{l}0.124^{* * *} \\
(79.31)\end{array}$ & $\begin{array}{l}0.196^{* * *} \\
(4.65)\end{array}$ \\
\hline sgrow2 & & & $\begin{array}{l}-1.215 \\
(-1.28)\end{array}$ \\
\hline lnoffice & & & $\begin{array}{l}1.258^{* * *} \\
(37.79)\end{array}$ \\
\hline bve_office & & & $\begin{array}{l}-0.000960^{*} \\
(-2.26)\end{array}$ \\
\hline ni_share_office & & & $\begin{array}{l}-0.00546^{* *} \\
(-2.81)\end{array}$ \\
\hline sgrow2_office & & & $\begin{array}{l}0.145^{*} \\
(2.49)\end{array}$ \\
\hline _cons & $\begin{array}{l}-5.302^{* * *} \\
(-5.56)\end{array}$ & $\begin{array}{l}-0.352 \\
(-0.35)\end{array}$ & $\begin{array}{l}-26.12^{* *} \\
(-25.19)\end{array}$ \\
\hline$N$ & 11174 & 11174 & 11174 \\
\hline
\end{tabular}

\section{CONCLUSION}

This study investigates whether investors perceive Big 4 auditors from large office provide higher audit quality comparing to those of Big 4 auditors from small office. The results from our regression analyses suggest that investors do place higher value for the audit work conducted by large size audit offices within Big-4 auditing firms. However, our further analyses indicate that the results cannot be generalized to those in non-Big-4 auditing firms.

\section{REFERENCES}

Becker, C., Defond, M., Jiambolvo. J., \& Subramanyam, K.R. (1998). The effect of audit quality on earnings management. Contemporary Accounting Research, 15(1), 1-24.

Choi, J., Kim, C., Kim, J., \& Zang., Y. (2010). Audit office size, audit quality and audit pricing. Auditing: A Journal of Practice and Theory, 29(1), 73-97.

Collins, D., \& Kothari, S.P. (1989). An analysis of intertemporal and cross-sectional determinants of earnings response coefficient. Journal of Accounting and Economics, 11(2-3), 143-181.

DeAngelo, L. (1981). Auditor size and auditor quality. Journal of Accounting and Economics, 3(3), 183199.

Francis, J., \& Ke, B. (2006). Disclosure of fees paid to auditors and the market valuation of earnings surprises. Review of Accounting Studies, 11(4), 495-523.

Francis, J., \& Krishnan, J. (1999). Accounting accruals and auditor reporting conservatism. Contemporary Accounting Research, 16(1), 135-165.

Francis, J., \& Yu, M. (2009). Big 4 office size and audit quality. The Accounting Review, 84(5), 15211552.

Francis, J., Reichelt, K., \& Wang, D. (2005). The pricing of national and city-specific reputations for industry expertise in the US audit market. The Accounting Review, 80(1), 113-136. 
Ghosh, A., \& Moon, D. (2005). Auditor tenure and perceptions of audit quality. The Accounting Review, $80(2), 585-612$.

Jia, H., \& Gates, S. (2018). Audit office size, client characteristics, and cost of bank loans. Journal of Accounting and Finance, 18(4), 11-22.

Lowensohn, S., Johnson, L., Elder, R., \& Davies, S. (2007). Auditor specialization, perceived audit quality, and audit fees in the local government audit market. Journal of Accounting and Public Policy, 26(6), 705-732.

Nelson, M., Elliott, J., \& Tarpley, R. (2002). Evidence from auditors about managers' and auditors' earnings management decisions. The Accounting Review, 77(Supplement), 175-202.

Ohlson, J. (1995). Earnings, book values, and dividends in equity valuation. Contemporary Accounting Research, 11(2), 661-687.

Reichelt K., \& Wang, D. (2010). National and office specific measures of office industry expertise and effect of audit quality. Journal of Accounting Research, 48(3), 647-686.

Reynolds, K., \& Francis, J. (2000). Does size matter? The influence of large clients on office-level auditor reporting decisions. Journal of Accounting and Economics, 30(3), 375-400.

Sundgren, S., \& Svanstrom,T. (2013). Audit office size, audit quality and audit pricing: Evidence from small-and-medium enterprise. Accounting and Business Research, 43(1), 31-55.

Teoh, S.H., \& Wong, T.J. (1993). Perceived auditor quality and the earnings response coefficient. The Accounting Review, 68(2), 346-366.

Wall Street Journal. (2020). Wirecard scandal put spotlight on auditor Ernest \& Young. Retrieved from https://www.wsj.com/articles/wirecard-scandal-puts-spotlight-on-auditor-ernst-young11593286933

Wallman, S. (1996). The future of accounting, Part III: Reliability and auditor independence. Accounting Horizons, 10(4), 76-97.

Watkins, A., Hillison, W., \& Morecroft, S. (2004). Audit quality: A synthesis of theory and empirical evidence. Journal of Accounting Literature, 23, 153 - 193. 